\title{
COMMUNITY-BASED TOURISM: A PANACEA FOR COMMUNITY DEVELOPMENT IN NQILENI VILLAGE, EASTERN CAPE, SOUTH AFRICA
}

\author{
Tshepiso Jonathan SETOKOE* \\ Walter Sisulu University Butterworth Campus, Department of Tourism and Hospitality Management, South Africa, e-mail: tsetokoe@wsu.ac.za
}

\begin{abstract}
Citation: Setokoe, T.J. (2020) COMMUNITY-BASED TOURISM: A PANACEA FOR COMMUNITY DEVELOPMENT IN NQILENI VILLAGE, EASTERN CAPE, SOUTH AFRICA. GeoJournal of Tourism and Geosites, 34(1), 28-32. https://doi.org/10.30892/gtg.34104-615
\end{abstract}

\begin{abstract}
This article investigates the viability of community-based tourism (CBT) in support of socio-economic development and poverty alleviation through a case study in Nqileni Village, Eastern Cape Province in South Africa. This was done through data solicited using a qualitative research approach amongst residents of Nqileni village in the Eastern Cape Province of South Africa. The data collected was then analysed using NVivo system, version 11, which provided substance to the research through the creation of a comprehensive observation report. The results indicated a positive view of members of the community relating to the contribution of CBT to community development (socio-economics) and poverty alleviation.
\end{abstract}

Key words: community-based tourism, development, capacity buiding, poverty alleviation, community development

\section{INTRODUCTION}

The 20th century has seen international organisation such as United Nations World Tourism Organisation (UNWTO), the World Travel and Tourism Council (WTTC), the World Bank, the World Trade Organisation (WTO) and the International Monetary Fund (IMF) take a keen interest in the diversification of development programmes (such as Sustainable Tourism for the Elim ination of Poverty programme) that can induce macro-economic growth in less developed countries (LDCs) (Scheyvens, 2007; Zatapa et al., 2011). This is given credence by reasons provided by a UNWTO (2004) stating reason that make tourism a development tool that can relate well to the needs of the world poor, articulated as follows:

- tourism is consumed at the point of production, providing an opportunity for direct interaction, additional purchases, and indirect income;

- rural areas, where most of the poor population live, are often rich in capital assets of great value for the tourist industry, such as music, art, wildlife, or climate;

- tourism is labour-intensive, providing more job opportunities for women and young people and new types of jobs and skills;

- tourism contributes to strengthening the social capital of the poor;

- tourism promotes the creation of small and micro-entrepreneurs;

- tourism supports the construction of public infrastructure and the conservation of natural and cultural heritage, providing cultural pride, greater awareness of the natural environment, and a sense of ownership in the communities.

The pretty picture painted by the outlook mentioned above is not without limitations. Empirical evidence has shown that even in the best case scenarios, moderate gains are accrued by the poor in terms of direct earnings and supply chain from the total tourist turnover of destinations (Mitchell and Ashley, 2007: 35; Irazábal, 2018). This is seen to concur with reports by Pluss and Backes (2002) and Spencer (2018) indicating the evaporation of the supposed economic benefits through leakage due to expatriate salaries (lack of local capacity), repatriation of profits, and/or import of goods (foreign investments). Development that is embedded in a pro-poor development paradigm is primarily founded on the ability of the area' economy to grow, thereby allowing for institutional pro-poor development initiatives to assume shape for the benefit of all, including the poor (Saayman and Giampiccoli, 2016; Hall, 2011; Gossling et al., 2010; Mowforth and Munt, 2003: 342). This is in stark contrast with the realities of the poor, as little or no evidence has come forward of tour ism being able to reduce poverty in areas acknowledged to be poverty stricken (Scheyvens, 2007; Pluss and Backes, 2002). UNWTO (2004) further makes a case for the previous authors stating that there have been significant declines in economies of LDCs where tourism was reported to have grown exponentially. Such has been affirmed by findings from the works of Sharpley (2009) and Manville and Kuhlmann (2018) indicating a per capita decline of $0.5 \%$ per annum since 2000 , making the communities poorer than they were in the 1970 s.

The limitations mentioned above can be attributed to unequal power relations that local communities (especially rural communities) often find themselves when dealing with external stakeholders (Zielinski et al., 2020a). This often devoids these communities a choice in the manner in which the communities can exercise authority in affairs of development within their habitat (Zielinski et al., 2020b). Such power relations are often based on the availabilty of resources such as finance, human and other social capital often endowed to external stakeholders (Zielinski et al., 2020a). The above bring an enquiry to the effectiveness of tourism as catalyst for destinations to generate revenue for governments of LCDs and enable capacity building (social and human) necessary to achieve consistent economic grow th. This article will focus on community-based tourism (CBT), as one of the primary development strategies aimed at supporting the sustainable socio-economic development and of a rural community.

\section{COMMUNITY - BASED TOURISM}

The development of tourism in earlier times (mass tourism) brought with it a range of undesirable and unintended consequences. This demanded of governments, developers and other stakeholders to seek alternative forms of tourism that will provide similar benefits, yet be less negative on the environment upon which tourism was dependent on (Hall and Lew, 2009: 230; Cater, 1993; Murphy, 1985: 8; De Kadt, 1979). This led to the emergence of CBT as a development model aimed at developing communities and reduce poverty with minimal negative impact on the environment (Zatapa et al., 2011). In addition, the model has always been associated with tourism activities in small rural communities, ecotourism and managerial models from around the world (Zatapa et al., 2011). Tourism as an area of study has for over

\footnotetext{
${ }^{*}$ Corresponding author
} 
three decades been a subject of a growing literature in the realm of sustainable development and community-based tourism (Dangi and Jamal, 2016). This has not absolved the discpline from the challenge of a lack of a concise definition. This is seen in Zapata et al (2011) indicating the difficulty of defining community-based tourism stemming from the definition's dependence on "who is defining it" and "where the community ends and the individual interests start". Consequently, practitioners have recognised community-based tourism to be a model of locally operated tourism that is owned and/or managed by host communities with the sole purpose of the accrual of positive benefits for the broader community (Dangi and Jamal, 2016), thereby achieving sustainable tourism development and community development. This rings true the assertions of contemporary literature and policy documents premising CBT on three main criteria, namely:

CBT is located within a community (i.e. on communal land or with community benefits such as lease fees),

- Owned by one or more community members (i.e. for the benefit of one or more community members) and,

- Managed by community members (i.e. community members could influence the decision making process of the enterprise) (Spenceley et al., 2016).

This affirms Dangi and Jamal's (2016) acknowledgement of sustainable tourism being oriented towards long-term sustainability, CBT extends the orientation to local-level participation, practices and management of tourism development, thereby providing real and tangible benefit to the person on the ground.

The promotion of CBT initiatives as a mechanism for sustainable development came into prominence in the early 1990s following the publication of the Brundtland Commission's landmark publication 'Our Common Future' (Imbaya et al., 2019). This saw developing countries undertake to subscribe to an industry seen to be capable of producing much needed economic benefits to communities in the periphery that will in normal circumstances not be able to participate in their own development without external support (Yanes et al., 2019). Such undertakings' credibility has a longer history dating back to the time of Gandhi (Petric and Pivcevic, 2016).

This is pointed out by Mansuri and Rao (2004: 4) stating the root of CBT to come from the Gandhian notion of self-reliance as an antidote of the corrosive effects of exogenous development perpetuated by colonial rule of the time. This was followed by a change in behaviour of rural communities who saw need in collective action for the purpose of pursuing a common goal (such as community-based approaches to development) as advocated by the Gandhian philosophy (Petric and Pivcevic, 2016; Soubry et al., 2020). This gave rise to what the world perceives to be new development paradigms within the sustainability umbrella, that aim to support and encourage selfreliance and the empowerment of communities (Yanes et al., 2019).

The advocacy of community-based development makes it popular for initiatives to depend on the employment of social capital in the organisation and participation of the local populace in development processes from the conception of the plan to its implementation and management (Petric and Pivcevic, 2016). This not only ensures that development initiatives increase local employment and income generation, but also assists in the development of skills, institutions and the empowerment of local people (Imbaya et al., 2019). This further ensures the intended empowerment of the community to encourage a pro-active role through community ownership, self-regulation and community-based management of tourism, thereby making sure that the tourism process affords participants a fair and equitable share of the benefits harnessed from development initiatives (Sripun et al., 2017). The picture painted above indicates a tourism that allows for a positive outlook that tourism can bring to a community. However, the development and management of tourism at a community level brings with it a political dimension that can threaten the success of any intended initiatives (Sripu et al., 2017). This is further compounded by the lack of a homogeneity and the diversity of interests amongst members of the community within a destination (Hall, 2007). More specific are challenges faced by efforts aimed at employing tourism as a tool for community development and poverty alleviation including but not limited to the availability of skills, knowledge of markets in the designing and development of product that match the needs of the market, limited access to information, capacity and capital (Imbaya et al., 2019; Moscardo, 2008: 6).

Given the myriad of challenges mentioned above, the development of community-based tourism is often marred by the host communities' ability to meaningfully and fully participate in tourism initiatives aimed at their development (Yanes et al., 2019). This rings truth to an old English saying - "give a man a fish, he will eat for a day; teach a man to fish he will eat forever". This is given credence by an ongoing debate within tourism development research circles on ensuring community participation that will safeguard the maximisation of community benefits and the equitable distribution of such benefits among community members (Durkin et al., 2017). Such endeavours require the recognition of the community's right be involved in any development initiatives aimed at the transformation and development of the destination they call home (Lindstrom and Larson, 2016). This further brings to the fore the limited applicability of tourism as a panacea for community development and poverty alleviation in rural settings due to the nature of community-based development theories cost of implementation (Taylor, 1995; Blackstock, 2005; Okazaki, 2008). Such costs are often associated with and limited to economics, whereas these require taking note of a requirement on the part of developers to perform a balancing act that will enable stakeholders to manage competing demands from all corners including economic, social and environmental demands from not only the local community, but also from government and external players such as investors (Sripu et al., 2017). The introduction of sustainable tourism development as a new global standard saw many countries shift from conventional tourism to integrating concepts such as community participation, empowerment, transparency, fairness, equity and quality into their national regulations and development strategies (Yanes et al., 2019). Despite the different spaces (political and cultural) under which community-based tourism practices occur, tourism of this nature has always been grounded in its intention to benefits host communities through community development initiatives, capacity building, local control and local enterprise development, poverty alleviation and the creation of sustainable livelihoods (Dangi and Jamal, 2016). This can be achieved through a systematic approach which requires an inter-disciplinary, participatory and holistic engagement of all components, thereby allowing for development that enables self-help, partnership (with external players such as investors) and mentoring of the community (by external players such as donors) (Amerta, 2017), which mostly centres around the full and meaningful participation of the host community.

The participation of a community in this context can be viewed as a mechanism that can be employed in exercises aimed at readjusting the balance of power and further entrench the affirmation of local views against those of developers and/or local authorities, which ultimately allows for the creation of conditions fertile for successful participation and prevent manipulation of a community in the participation process (Tosun, 2000). Recent tourism development literature indicates the involvement of local communities to be an integral part of the tourism development agenda (Tuson, 2006; Aref et al., 2010; Muganda et al., 2013). In addition, involvement of locals in tourism development has been argued to produce further positive returns such as high satisfaction in relation to development initiatives and an even higher tolerance for to tourists (Timothy and Boyd, 2003: 61; Tosun, 2003; Su and Wall, 2014). This sees Tosun (2000) citing Stone (1989: 207) in stating that the objective of community participation is to design 'development in such a way that intended beneficiaries are encouraged to take matters into their own hands, to participate in their own development through mobilising their own resources, defining their own needs, and making their own decisions about how to meet them'. This places the community in the centre of development, since community participation as a strategy requires resources owned by the community in order to fulfil the needs of the community (Tosun, 2000). 


\section{MATERIAL AND METHODS}

A qualitative research approach that was reliant on a semi-structured interviews was employed for the study. The collection of empirical data was undertaken through the use of a non-probability purposive sampling technique at a rural village of Nqileni which houses the Bulungula Lodge, a tourism project owned and managed by the community. This project is a community-based tourism enterprise aimed at the development of the Nqileni community with initiatives in education, health and infrastructure (Bulungula, 2015). The chosen sample included interviews with five (5) members of the community in their capacity as community leaders (local headman, ward councillor, ward committee member, manager of Bulungula lodge and local economic development officer for Mbashe Local Municipality) together with 19 members of the general community (inclusive of local entrepreneurs, employees of tourism enterprises and residents not involved in tourism activities). The data was collected in the language of the local community (isiXhosa), which was then transcribed and translated into English and analysed using NVivio software version 11. Subsequent to the analysis, a comprehensive observation report was produced, allowing the researcher to present the findings and a discussion that will contribute to the body of knowledge within the community-based tourism arena.

\section{RESULTS AND DISCUSSION}

The empirical data collected for the study was subjected to analysis that produce themes indicative of community-based tourism being catalyst for socio economic development and poverty alleviation in Nqileni village. These themes were formulated following narratives from respondents in relation to CBT being a panacea for the development of Nqileni village. These include the development of community resources, capacity building through community participation and poverty alleviation. These have enabled the study to present and discuss the findings as per responses derived from respondents that participated in the study.

\section{Development of community resources and infrastructure}

A common narrative amongst the community of Nqileni village, in relation to CBT being a panacea of community development centred on the development of infrastructure and resources that followed the development of tourism in the village through the establishment of Bulungula Lodge. This brought forth a narrative that described development to entail access to basic services such as water and electricity, as well as proper roads and infrastructure, with the development of people and the Bulungula lodge also being a key constituent. The Lodge was constantly credited with several developments (such as the availability of running water, solar panels and a proper road connecting the village with other areas). Additional narratives of eradication of poverty and the sustainable realisation of self-reliance and self-sufficiency were also brought forward. These narratives have been consistent amongst respondents and are presented as follows:

"I think it would refer to people being developed and having access to water and electricity and proper roads."

"Before the establishment of lodge, we did not have infrastructure such as proper roads, running water and solar panel. The lodge has now made these developments possible."

"The first thing I can think of is the establishment of the lodge as it has brought about change in our lives. Before the lodge, we did not have jobs, but now there is something that we are getting, as small as it is."

The understanding of development by the general community of Nqileni village is given credence by assertions of Jeon et al., (2016), indicating the contribution of tourism to the development and sustainability of the local environment, through the accrual of benefits of improvement of the local infrastructure, the protection of the physical environment, and the enhancement of economic prosperity of the people. This is also seen to agree with the prescripts of the South African National Development Plan (NDP) (2011) in relation to the provision of basic services that enable people to develop the capabilities they need to take advantage of economic opportunities throughout the country and contribute towards the development of their communities through remittances and the transfer of skills.

\section{Capacity building through participation}

The community provides a unique perspective of the importance of community participation in rural development, which leads to the building of capacity of the community to develop. This is seen in articulations related to the community's undertaking to participate in development initiatives emerging due to the development of tourism in Nqileni village. They mention, among other things, the local community's participation in the development of infrastructure (such as construction of roads, provision of water and other social facilities) and the development of businesses that serve tourists and the community at large, therby gaining the capacity to maintain the said infrastructure and sustain the business created. The respondents further allude to the engagements undertaken by the collective in terms of consultation of, and input given by, members of the community when it comes to development projects introduced to the village. This is orated as follows:

"The establishment of businesses by members of the community has been a key factor to community participation in the development of Nqileni village." "I think it is important for people to be trained so that they can meaningfully participate in tourism."

"Since the establishment of Bulungula lodge, providers of service to tourists have been trained in skills to aimed at serving the tourists."

"We now have creches at Bulungula Incubator and the teachers are member of the Nqileni village community"

"And having genuine meetings where there is an ability to shift your understanding of things. It's not just an information session. It's (Indistinct) giving the community an opportunity to have a say so in what it is

"Um...it's a first consultation. I don't think you're gonna have community...genuine community participation that means nothing can happen in the village without consulting the community."

The narrative points to a symbiotic relationship between participation in development initiatives and capacity building, whic h has a transformative ability to influence the way people conduct their affairs. This gives credence to the work of Petric and Pivcevic (2016) stating a history of such undertakings to date back to the time of Gandhi. This is pointed out by Mansuri and Rao (2004: 4) stating the root of CBT to come from the Gandhian notion of self-reliance as an antidote of the corrosive effects of exogenous development perpetuated by colonial rule of the time. This rings truth to an old English saying - "give a man a fish, he will eat for a day; teach a man to fish he will eat forever". This then requires a change in behaviour of rural communities who saw need in collective action for the purpose of pursuing a common goal (such as community-based approaches to development) as advocated by the Gandhian philosophy (Petric and Pivcevic, 2016; Soubry et al., 2020). These are given credence by undertakings that are aimed at ensuring community participation that will safeguard the maximisation of community benefits and the equitable distribution of such benefits among community members (Durkin et al., 2017). Such endeavours require the recognition of the community's right be involved in any development initiatives aimed at the transformation and development of the destination they call home (Lindström and Larson, 2016).

\section{Positive multiplier leading to poverty alleviation}

Respondents elucidated on the role of tourism development in the economy of the area, and its concerted efforts in the alleviation of poverty. This is made evident in the credit given to the development of tourism for the creation of employment and the increase in 
entrepreneurial concerns within the area. Such developments are indicated not to be limited to the tourism space, as other economic sectors (such as agriculture, fishery and retail, to mention a few) have seen a considerable injection of business following the development of tourism in the area. Furthermore, the development of tourism has also afforded community members with skills and talents in indigenous arts and crafts to enter the market space and generate an income through their wares. This has seen the emergence of a vibrant community of active participants in tourism related economic activities. This is presented by respondent narratives as follows:

"If it weren't for the lodge, we would be starving."

"Tourism plays a role of alleviating poverty. Before the establishment of Bulungula lodge, people were not employed and there was nothing to do. Now, we are able to put food on the table and use our talents to get an income."

"I have money now. I am able to send my kids to school."

"Tourism helps us financially."

"People are able to earn an income because of the tourists that visit here." "The revenue that we make out of what we get from tourists that come here assists us to achieve some of our goals."

"Because of tourism we are able to provide for our families. For example: There are people who have built their homes because there is tourism."

Even with the positive multiplier effect demonstrated above, there is however, a voice of despondency (isolated cases) that brought to the fore the limited direct employment opportunities provided by tourism (specifically the Bulungula lodge employing 23 people) in Nqileni village with a population of 1500 . This gives a clear indication of the great unemployment challenges faced by rural areas, even with development initiatives of this nature. However, respondents further proclaim the beneficiation of the community from tourism, irrespective of employment status, through a community trust (Bulungula Trust) established to ensure that every indigenous resident of the village benefits from the wholly community-owned and run Bulungula Lodge. This is stated to be a scheme that equitably distributes benefits and costs associated with tourism within the village. The issues tabled above are given credence by respondents' statements that follow:

"Ja, I don't know. It's a difficult question because I don't think tourism is the panacea to the rural development challenges. Uh...you know, like I said, the lodge employs 23 people. Nqileni has a population of 1500. So, it's not gonna solve all employment problems, you know. It's not the panacea to those things. But I think...I think if you do it well you can get good jobs, meaningful work, um... with good cross-world exposure. If you do it badly it can be horrible for communities. But if you do it well it can be good."

"Much as unemployment is a big problem in the area, those of us who are not employed do receive dividends from profits made by the lodge through the Bulungula Trust."

"I have personally benefitted from the proceeds of the lodge through having my daughter's school being paid for by the Bulungula Trust."

The findings on the role of tourism in the sustainable satisfaction of community needs, and the fight against uncertainty, is congruent with the discourse of sustainable tourism, as it rests upon the proper management of host community resources, with the aim to meet the fundamental criteria of promoting socio-economic wellbeing and livelihood of the local community, without compromising the satisfaction of the needs of the tourists (Malik and Bhat, 2015). This has been seen to be evident in the significant effect tourism expenditure has on many destinations, especially in the developing world, irrespective of whether the effect is direct, indirect or induced (Brida and Zapata, 2009). This can be exemplified by direct employment created by the Bulungula Lodge for local residents, to gether with locally owned and managed businesses established to serve tourists visiting the Nqileni village, with indirect benefits derived from local fresh produce providers selling vegetables, fruits, meat and fish to the Lodge for tourist consumption, and induced ben efits realised with the establishment of the Bulungula Incubator, a Non-Governmental Organisation (NGO) established for purposes of community development established in 2007 as a result of the establishment of the Lodge in 2004 (Bulungula, 2016).

This is further affirmed by Dorobantu and Nistoreanu (2012), who state that the positive contribution to state revenue by tourist spending, together with the traffic of complementary goods (imports and exports) for the receiving area and the attraction of foreign investment, culminates into a multiplier effect that sees tourism contribute to the economic prosperity of the area. Such prosperous endeavours need to be undertaken with the assurance of equality, so as not to allow any exclusionary or discriminatory practices that could hinder people from participating economically, socially and politically in matters of development in society.

\section{CONCLUSION}

The contribution of CBT to community development has been evident through literature and empirical data presented and discuss ed in the study. Such contribution has been seen to ensure that development initiatives within the tourism space bring benefits that not only provide benefits at the moment of interaction, but allow for the community to derive sustainable attributes that can enable development that is endogenous and release the community from dependence on exogenously-based development initiatives. This can be seen in CBT's ability to stimulate an entrepreneurial culture that leads to the creation of employment, income generation, skills dev elopment and ultimately the empowerment of the local populace. The notion of CBT having ability to contribute in community development is not without limitations. Much as evidence indicates the positive contribution of CBT to community development, there is also a si gnificant voice of opposition that asserts that the gains perpetuated by advocates of tourism being advanced as a tool for development are too miniscule for the investment communities are required to make. This makes it necessary for CBT initiatives to ensure proper management of the impacts of tourism on the economy, society and environment will bring benefits to Nqileni village. Such can see to assist in the levelling of the playing field as far as the distribution of benefits is concerned, thereby minimizing the voice of discontent amongst members of the community (note that these voices were few in the findings). The study recommends for benefits of CBT to be spread throughout the area and the community. This is important, because the resources utilised for the development belong to the community as a whole, and beneficiation of one over the other can threaten the sustainability of the development. Instruments such as community trusts (such as Bulungula Trust in Nqileni village) that can ensure equitable distribution of benefits are recommen ded.

Finally, the study made no intention to claim authority on the ability of CBT to be a panacea for community development, but an attempt to investigate the manner in which tourism can be employed as a development option for rural areas that are in dire shortage of opportunity and ravaged by poverty. The study finally concludes with a recommendation of a need for a collaborative and focused approach that will enable more meaningful community participation in development initiatives such as CBT, which eventually result in community development. This is surmised from evidence obtained from the empirical data collected suggesting that if CBT is planned and implemented correctly, with proper consultations and involvement of community members, it can positively contribute to the development of a community.

\section{REFERENCES}

Amerta, I.M.S. (2017). Community based tourism development. International Journal of Social Sciences and Humanities, 1(3), 97-107. https://doi.org/10.21744/irjmis.v7n1.819

Aref, F., Gill, S.S., \& Aref, A. (2010). Tourism development in local communities: as a community development approach. Journal of American Science, $27,155-161$. 
Blackstock, K. (2005). A critical look at community based tourism. Community Development Journal, 40(1), 39-49. https://doi.org/10.1093/cdj/bsi005

Brida, J.G., \& Zapata, S. (2009). Cruise tourism: economic, socio-cultural and environmental impacts. International Journal of Leisure \& Tourism Marketing, 1(3), 205-226.

Cater, E. (1993). Ecotourism: A Sustainable Option. Geographical Journal, 159(5), 114-115.

Dangi, T.B., \& Jamal, T. (2016). An integrated approach to sustainable community-based tourism. Sustainability, 8(5). 475-507. https://doi.org/10.3390/su8050475

de Kadt, E. (1979). Social planning for tourism in the developing countries. Annals of Tourism Research, 6(1) 36-48. https://doi.org/10.1016/0160-7383(79)90093-8

Dorobantu, M.R., \& Nistoreaunu, P. (2012). Rural tourism and ecotourism - the main priorities in sustainable development orientation of rural local communities in Romania. Economy Transdisciplinary Cognition, 1, 259-266. https://mpra.ub.uni-muenchen.de/31480/

Durkin, J., Perić, M., \& Sebrek, J.K. (2017). Addressing organisational challenges of cultural tourism in rural areas through community-based tourism model. International Scientific Conference Tourism in Southern and Eastern Europe, 4, 145-157. https://doi.org/10.20867/tosee.04.29

Gossling, S., Hall, C.M., Peeters, P., \& Scott, D. (2010). The future of tourism: Can tourism growth and climate policy be reconciled? A mitigation perspective. Tourism Recreation Research, 35(2), 119-130. https://doi.org/10.1080/02508281.2010.11081628

Hall, C.M. (2007). Pro-poor tourism: Do 'tourism exchanges benefit primarily the countries of the south'? Current Issues in Tourism, 10(2-3), 111-118. https://doi.org/10.1080/13683500708668426

Hall, C.M., \& Lew, A.A. (2009). Understanding and managing tourism impacts: An integrated approach. New York: Routledge.

Hall, C.M. (2011). Policy learning and policy failure in sustainable tourism governance: from first-and second-order to third-order change? Journal of Sustainable Tourism, 19(4-5), 649-671. https://doi.org/10.1080/09669582.2011.555555

Imbaya, B.O., Nthiga, R.W., Sitati, N.W., \& Lenaiyasa, P. (2019). Capacity building for inclusive growth in community-based tourism initiatives in Kenya. Tourism Management Perspectives, 30, 11-18. https://doi.org/10.1016/j.tmp.2019.01.003

Irazábal, C. (2018). Coastal urban planning in the 'Green Republic': Tourism development and the nature-infrastructure paradox in Costa Rica. International Journal of Urban and Regional Research, 42(5),882-913. https://doi.org/10.1111/1468-2427.12654

Jeon, M.M., Kang, M.M, \& Desmarais, E. (2016). Residents' perceived quality of life in a cultural-heritage tourism destination. Applied Research in Quality of Life, 11(1), 105-123. http://dx.doi.org/10.1007/s11482-014-9357-8

Lindström, K.N., \& Larson, M. (2016). Community-based tourism in practice: evidence from three coastal communities in Bohuslän, Sweden. Bulletin of Geography, Socio-economic Series, 33(33), 71-78. http://dx.doi.org/10.1515/bog-2016-0025

Malik, M.I, \& Bhat, M.S. (2015). Sustainability of tourism development in Kashmir-Is paradise lost? Tourism Management Perspectives, 16, 11-21. https://doi.org/10.1016/j.tmp.2015.05.006

Mansuri, G., \& Rao, V. (2004). Community-based and-driven development: A critical review. The World Bank Research Observer, 19(1), 1-39. https://doi.org/10.1093/wbro/lkh012

Manville, M., \& Kuhlmann, D. (2018). The social and fiscal consequences of urban decline: Evidence from large American cities, 1980-2010. Urban Affairs Review, 54(3), 451-489. https://doi.org/10.1177/1078087416675741

Mitchell, J., \& Ashley, C. (2007). Pathways to prosperity - how can tourism reduce poverty: A review of pathways, evidence and methods. Washington, DC: World Bank/ODI.

Moscardo, G. (2008). Building community capacity for tourism development. Australia: Cabi Publication.

Mowforth, M., \& Munt, I. (2003). Tourism and sustainability: Development and new tourism in the Third World. London: Routledge.

Murphy, P.E. (1985). Tourism a Community Approach. New York: Methuen, Inc.

Muganda, M., Sirima, A., \& Ezra, P. M. (2013). The role of local communities in tourism development: grassroots perspectives from Tanzania. Journal of Human Ecology, 41(1), 53-66. https://doi.org/10.1080/09709274.2013.11906553

Okazaki, E. (2008). A community-based tourism model: Its conception and use. Journal of Sustainable Tourism, 16(5), 511-529. https://doi.org/10.1080/09669580802159594

Petric, L., \& Pivcevic, S. (2016). Community based tourism development-insights from Split, Croatia. In Faculty of Tourism and Hospitality Management in Opatija. Biennial International Congress. Tourism \& Hospitality Industry, Accessed 25/06/2020. https://www.researchgate.net/profile/ Smiljana_Pivcevic/publication/330161967_Community_based_tourism_development__insights_from_Split_Croatia/links/5c3081d092851c22 a35b8e7b/ Community-based-tourism-development-insights-from-Split-Croatia.pdf

Pluss, C., \& Backes, M. (2002). Red card for tourism? 10 principles and challenges for a sustainable tourism development in the 21 st century. Freiburg: Dante.

Saayman, M., \& Giampiccoli, A. (2016). Community-based and pro-poor tourism: Initial assessment of their relation to community development. European Journal of Tourism Research (Online). http://openscholar.dut.ac.za/bitstream/10321/2230/1/SaaymanEJTR_Vol12_Pg145-190_2016.pdf

Scheyvens, R. (2007). Exploring the tourism - poverty nexus. Current Issues in Tourism, 10(2), 231-224. https://doi.org/10.2167/cit318.0

Sharpley, R. (2009). Tourism development and the environment: beyond sustainability? London: Earthscan.

Soubry, B., Sherren, K., \& Thornton, T.F. (2020). Farming along desire lines: Collective action and food systems adaptation to climate change. People and Nature, 2(2), 420-436. https://doi.org/10.1002/pan3.10075

Spenceley, A., Rylance, A., Nanabhay, S. \& van der Watt, H. (2016). Operational Guidelines for Community-based Tourism in South Africa. Department of Tourism: Republic of South Africa

Spencer, A. (2018). Travel and tourism in the Caribbean: challenges and opportunities for small island developing states. Bahamas: Springer.

Sripun, M., Yongvanit, S., \& Pratt, R. (2017). Power, legitimacy, and urgency of community-based tourism stakeholders in north-eastern Thailand. Asian Social Science, 13(4), 104-116.

Stone, L. (1989). Cultural cross-roads of community participation in development: a case from Nepal. Human Organisation, 48(3), 206-213. https://doi.org/0018-7259/89/030206-08\$1.30/1

Su, M. M., \& Wall, G. (2014). Community participation in tourism at world heritage site: Mutianyu great Wall, Beijing China. International Journal of Tourism Research, 16(2), 146-156. https://doi.org/10.1002/jtr.1909

Taylor, G. (1995). The community approach: does it really work? Tourism management, 16(7), 487-489. https://doi.org/10.1016/0261-5177(95)00078-3

Timothy, D.J., \& Boyd, S. W. (2003). Heritage tourism. Edingburg Gate: Pearson Education Limited.

Tosun, C. (2000). Limits to community participation in the tourism development process in developing countries. Tourism Management, 21, 613-633. https://doi.org/10.1016/S0261-5177(00)00009-1

Tosun, C. (2005). Stages in the emergence of a participatory tourism development approach in the developing world. Geoforum, 36(3), 333-352. https://doi.org/10.1016/j.geoforum.2004.06.003

Tosun, C. (2006). Expected nature of community participation in tourism development. Tourism Management, 27, 493-504. https://doi.org/10.1016/j.tourman.2004.12.004

Yanes, A., Zielinski, S., Diaz Cano, M., \& Kim, S.I. (2019). Community-based tourism in developing countries: A framework for policy evaluation. Sustainability, 11(9), 2506. https://doi.org/10.3390/su11092506

Zapata, M.J., Hall, C.M., Lindo, P., \& Vanderschaeghe, M. (2011). Can community-based tourism contribute to development and poverty alleviation? Lessons from Nicaragua. Current Issues in Tourism, 14(8), 725-749. https://doi.org/10.1080/13683500.2011.559200

Zielinski, S., Kim, S., Botero, C., \& Yanes, A. (2020). Factors that facilitate and inhibit community-based tourism initiatives in developing countries. Current Issues in Tourism, 23:6, 723-739. https://doi.org/10.1080/13683500.2018.1543254

Zielinski, S., Jeong, Y., \& Milanés, B.M. (2020). Factors that influence community-based tourism (CBT) in developing and developed countries. Tourism Geographies, 1-33. https://doi.org/10.1080/14616688.2020.1786156

*** Bulungula. (2020). Bulungula lodge. accessed 09/06/2020. https://bulungula.com

*** Bulungula Incubator. (2016). 2016 Annual Report. accessed 09/06/2020. https://bulungulaincubator.wordpress.com/about/

*** South Africa. (2011). National Development Plan. accessed 27/06/2020. http://www.gov.za/sites/www.gov.za/files/devplan_2.pdf

*** United Nation World Tourism Organisation (UNWTO). (2004). Tourism and poverty alleviation recommendations for action. Madrid. 